\title{
PENGARUH MINAT BELAJAR SISWA DAN PERSEPSI ATAS UPAYA GURU DALAM MEMOTIVASI BELAJAR SISWA TERHADAP PRESTASI BELAJAR BAHASA INDONESIA SISWA SMP DI DEPOK
}

\author{
Vina Rahmayanti \\ Program Studi Teknik Informatika, Universitas Indraprasta PGRI \\ Email: vinarahmayanti_87@yahoo.com
}

\begin{abstract}
Abstrak
Tujuan penelitian ini di antaranya untuk mengetahui hubungan antara minat belajar siswa dan prestasi belajar bahasa Indonesia, mengetahui hubungan antara upaya guru dalam memotivasi belajar siswa terhadap prestasi belajar bahasa Indonesia, dan mengetahui hubungan minat belajar siswa dan upaya guru dalam memotivasi belajar siswa secara bersama-sama terhadap prestasi belajar bahasa Indonesia. Metode yang digunakan dalam penelitian ini adalah survei. Sampel berjumlah 78 siswa yamg dipilih dengan teknik gabungan antara acak dan proporsional. Pengumpulan data dilaksanakan dengan menggunakn kuesioner, yaitu denagan skala Likert dan menggunakan teks dalam soal pilihan ganda. Siswa diminta memilih pernyataan yang sesuai dengan yang mereka alami dengan memilih SS untuk sangat setuju, S untuk setuju, R untuk ragu-ragu, TS untuk tidak setuju, dan STS untuk sangat tidak setuju. Soal untuk kuesioner minat belajar berjumlah 30 soal dan soal untuk motivasi belajar berjumlah 15 soal. Setelah dianalisis maka dihasilkan bahwa semakin baik persepsi atas upaya guru dalam memotivasi belajar siswa diikuti oleh semakin baiknya prestasi belajar bahasa Indonesia siswa. Penelitian ini dilakukan dengan sampel siswa kelas XI sekolah menengah pertama swasta di Depok, yaitu SMP Gelora Depok.
\end{abstract}

Kata Kunci: Minat, Motivasi, Prestasi Belajar.

\section{Pendahuluan}

Motivasi merupakan hal yang berperan pada kemajuan, dan perkembangan siswa dalam proses belajar. Bila motivasi guru tepat mengenai sasaran akan meningkatkan kegiatan belajar. Tujuan yang jelas membuat siswa akan belajar lebih tekun, lebih giat dan bersemangat. Motivasi adalah syarat mutlak untuk belajar. Di sekolah seringkali terdapat anak yang malas, tidak menyenangkan, suka membolos dan sebagainya. Dalam hal demikian berarti bahwa guru tidak berhasil memberikan motivasi yang tepat untuk mendorong agar ia bekerja dengan segenap tenaga dan pikirannya. Dalam hubungan ini, perlu diingat bahwa nilai buruk pada suatu mata pelajaran tertentu belum tentu berarti anak itu bodoh terhadap mata pelajaran itu.

Seringkali terjadi anak malas terhadap suatu mata pelajaran, tetapi sangat giat dalam mata pelajaran lain. Hal ini juga termasuk minat siswa, minat belajar siswa merupakan salah satu faktor penting dalam keberhasilan pendidikan dan pengajaran.Untuk dapat melaksanakan hal itu, kita sebagai pendidik harus dapat membina dan meningkatkan minat belajar siswa agar siswa dapat memperoleh hasil belajar yang diinginkan.

Banyak siswa yang kurang termotivasi atau berminat mempelajari bahasa Indonesia karena banyak sebab dan hal, seperti kurang populernya pelajaran bahasa Indonesia dibanding bahasa asing lainnya, menganggap bahasa Indonesia sebagai bahasa mereka sejak lahir sehingga kurang berminat mempelajarinya, sampai merasa pelajaran ini membosankan. Padahal pemerintah sendiri telah memasukkan bahasa Indonesia sebagai pelajaran yang di ujikan dalam Ujian Nasional agar siswa mau dan mampu menguasai pelajaran bahasa Indonesia, tetapi pada kenyataannya pelajaran ini masih saja tidak begitu diminati oleh siswa. 
Selain motivasi, adanya minat siswa dalam mengolah dan mengerjakan soal bahasa Indonesia menjadi penyebab rendahnya hasil belajar bahasa Indonesia. Banyak siswa merasa jenuh, bosan dan bahkan menganggap pelajaran bahasa Indonesia pelajaran yang gampang jadi tidak terlalu mendapat perhatian khusus bagi siswa dalam pengerjaannya. Mereka cenderung merasa malas untuk membaca soal yang lebih banyak informasi dan bacaan tersebut. Siswa juga beranggapan bahwa bahasa Indonesia merupakan bahasa mereka dari kecil jadi mereka merasa mampu dan kurang motivasi untuk mengikuti pelajaran bahasa Indonesia yang tanpa mereka sadari akhirnya membawa mereka mendapatkan nilai yang tidak maksimal. Dalam mengerjakan atau mengikuti pelajaran bahasa Indonesia, siswa kurang motivasi hingga kurang juga mempergunakan intelegensi dan kreativitas yang mereka miliki untuk memahami bentuk pelajaran bahasa Indonesian yang beragam.

Selain potensi, manusia juga lahir dikaruniai naluri yaitu dorongan-dorongan alami, seperti dorongan makan, tidur dan sebagainya. Seandainya manusia hidup hanya dengan naluri tanpa akal, pikiran dan perasaan, maka tidak ada bedanya dengan binatang. Hanya dengan akal pikiran tersebut manusia dapat dididik agar dapat mengadakan perubahan-perubahan sehingga menjadi makhluk yang paling mulia di dunia ini. Hanya dengan pendidikanlah status hewan itu bisa diubah menjadi status manusia.

Pendidikan memang untuk manusia, karena hanya manusialah yang dapat di didik. Manusia selain memiliki kemampuan seperti yang dimiliki makhluk lainnya, juga memiliki kemampuan khusus yaitu kecerdasan dan kemauan. Apabila kemampuan khusus tersebut dapat dikembangkan secara optimal, maka manusia itu merupakan makhluk yang paling tinggi derajatnya dan paling mulia kedudukannya. Sebaliknya, bila manusia tidak mendapat pendidikan cukup, maka akan lebih rendah dari hewan. Itulah pendidikan dapat memanusiakan manusia.

Pendidikan memegang peranan penting dalam mempersiapkan sumber daya manusia yang berkualitas. Oleh karena itu, pendidikan hendaknya dikelola, baik secara kualitas maupun kuantitas. Hal tersebut bisa tercapai bila pelajar dapat menyelesaikan pendidikan tepat pada waktunya dengan hasil belajar yang baik. Hasil belajar seseorang ditentukan oleh berbagai faktor yang mempengaruhinya. Salah satu faktor yang ada di luar individu adalah tersedianya bahan ajar yang memberi kemudahan bagi individu untuk mempelajarinya, sehingga menghasilkan belajar yang lebih baik. Belajar mengajar adalah suatu kegiatan yang bernilai edukatif. Nilai edukatif mewarnai interaksi yang terjadi antara guru dengan-anak didik. Interaksi yang bernilai edukatif dikarenakan kegiatan belajar mengajar yang dilakukan diarahkan untuk mencapai tujuan tertentu yang telah dirumuskan sebelum pengajaran dilakukan. Guru dengan sadar merencanakan kegiatan pembelajarannya secara sistematis dengan memanfaatkan segala sesuatunya guna kepentingan pengajaran. (Djamarah, 2006).

Mengingat belajar adalah proses bagi siswa dalam membangun gagasan atau pemahaman sendiri, maka kegiatan belajar mengajar hendaknya memberikan kesempatan kepada siswa untuk melakukan hal itu secara lancar dan termotivasi. Suasana belajar yang diciptakan guru harus melibatkan siswa secara aktif, misalnya mengamati, bertanya dan mempertanyakan, menjelaskan, dan sebagainya. Belajar aktif tidak dapat terjadi tanpa adanya partisipasi peserta didik. Terdapat berbagai cara untuk membuat proses pembelajaran yang melibatkan keaktifan siswa dan mengasah ranah kognitif, afektif, dan psikomotorik. Proses pembelajaran aktif dalam memperoleh informasi, keterampilan, dan sikap akan terjadi melalui suatu proses pencarian dari diri siswa. Para siswa hendaknya lebih dikondisikan berada dalam suatu bentuk pencarian daripada sebuah bentuk reaktif. Siswa mencari jawaban terhadap pertanyaan baik yang dibuat oleh guru maupun yang ditentukan oleh mereka sendiri. Semua ini dapat terjadi ketika siswa diatur sedemikian rupa sehingga berbagai tugas 
dan kegiatan yang dilaksanakan sangat mendorong mereka untuk berpikir, bekerja, dan merasa.

Dari uraian di atas, jelas kiranya motivasi sangat berpengaruh dalam proses belajar dan memerlukan bantuan orang lain dan dirinya sendiri untuk membangkitkan motivasi yang ada dalam dirinya. Dalam hal ini, guru menjadi motivator yang sangat diperlukan untuk membangkitkan dan mengembangkan prestasi belajar.

Memotivasi murid adalah menciptakan kondisi sedemikian rupa sehingga anak itu melakukan apa yang bisa dilakukannya. Beberapa eksperimen membuktikan adanya peranan yang sangat besar untuk membangkitkan aktivitas dan gairah belajar. Untuk itu, guru yang merupakan motivator terbesar dalam proses belajar perlu memperhatikan dan mempertimbangkan dua jenis motivasi agar tepat dan dapat diterima dengan baik.

Kedua jenis motivasi ini adalah motivasi intrinsik dan ekstrinsik. Kedua jenis motivasi ini sangat perlu diperhatikan untuk mengoptimalkan peranan guru dalam memberi motivasi untuk meningkatkan prestasi belajar dan mengatasi masalah dalam belajar akibat kurangnya motivasi dan minat belajar. Jelas kiranya bahwa motivasi sangat berpengaruh dalam proses belajar dan memerlukan bantuan orang lain dan dirinya sendiri untuk membangkitkan motivasi yang ada dalam dirinya. Dalam hal ini, guru menjadi motivator yang sangat diperlukan untuk membangkitkan dan mengembangkan prestasi belajar.

Untuk membantu menarik minat dan perhatian siswa, guru dapat menggunakan berbagai cara seperti cara belajar yang baik, alat peraga yang cukup, intonasi yang tepat dan humor mungkin juga menggunakan contoh yang tepat dan sebagainya. Jadi jelaslah bahwa sebagai guru harus memotivasi siswa dan harus banyak mencari cara dan alternatif-alternatif yang dapat menarik minat siswa dalam mengikuti pelajaran. Oleh karena itu, akan sangat efektif jika guru dan segenap yang mempengaruhi motivasi dan minat belajar siswa bekerja sama dengan baik agar tercapainya tujuan belajar yang efektif dan efisien. Hasil penelitian ini diharapkan dapat dijadikan gambaran tentang seberapa besar pengaruh minat belajar siswa dan persepsi atas upaya guru dalam memotivasi siswa kelas IX SMP terhadap prestasi belajar bahasa Indonesia.

\section{Tinjauan Pustaka}

Salah satu faktor yang mempengaruhi belajar adalah perilaku non-kognitif. Perilaku nonkognitif yang dimaksudkan itu adalah minat. Selain itu, minat juga merupakan salah satu aspek psikis manusia yang dapat mendorongnya untuk mencapai tujuan. Seseorang yang memiliki minat terhadap suatu objek, cenderung untuk memberikan perhatian yang lebih besar terhadap objek tersebut. Jadi, jika dikaitkan dengan pembelajaran, faktor minat mungkin dapat mempengaruhi hasil belajar seseorang. Berikut beberapa pendapat ahli, dikemukakan agar kita mendapat gambaran lebih jelas.

Menurut Arthur (1963), minat sebagai perasaan suka yang berhubungan dengan suatu reaksi terhadap suatu yang khusus atau situasi tertentu. Garret (1965), menjelaskan sebagai aktivitas yang menyertai seorang individu melalui nilai-nilai, perasaan-perasaan, dan pikiranpikiran yang disukainya. Thorndike dan Elizabeth, (1977), merumuskan minat sebagai kecenderungan yang berkenaan dengan partisipan dan mencari pilihan yang disukai dalam aktivitas-aktivitasnya.

Seiring dengan pengalaman belajar yang menimbulkan kebahagiaan, minat anak akan terus tumbuh. Apabila anak memperoleh keterikatan kepada kegiatan-kegiatan dari pelajaran yang dialaminya, ia akan merasa senang. Oleh karena itu, minat terhadap mata pelajaran harus 
ditimbulkan di dalam diri anak, sehingga anak terdorong untuk mempelajari berbagai ilmu yang ada di kurikulum sekolah.

Menurut Gagne dan Berliner (1984), anak dengan minat dalam suatu mata pelajaran cenderung untuk memberikan perhatiannya. Mereka merasakan adanya perbedaan antara pelajaran satu dengan pelajaran lainnya. Perbedaan yang dirasakan adalah belajar dengan penuh kesadaran, belajar dengan gembira, perhatian tinggi, belajar dengan keras dan memperoleh kepuasan yang tinggi.

Selanjutnya, Nasution (1981) menjelaskan bahwa minat adalah sesuatu yang sangat penting bagi seseorang dalam melakukan kegiatan dengan baik. Sebagai suatu aspek kejiwaan, minat bukan saja dapat mewarnai perilaku seseorang, tetapi lebih dari itu minat mendorong orang untuk melakukan suatu kegiatan dan menyebabkan seseorang menaruh perhatian dan merelakan dirinya untuk terikat pada suatu kegaitan.

Akhirnya, Raminah Barbirin (1990) memberikan penjelasannya tentang minat yang memberikan pengertiannya sebagai kesadaran seseorang bahwa suatu objek, orang, hal, atau keadaan mempunyai hubungan atau kepentingan baginya. Minat harus dianggap sebagai respons sadar, jika tidak, respon itu sama sekali tidak bermakna.

Pendapat tersebut di atas pada dasarnya mempunyai banyak kesamaan pengertian. Meskipun dalam bahasa dan rumusan yang berbeda, arah dan sasaran objeknya sama. Berikut intisari dan pokok-pokok pikiran dari berbagai pendapat ahli.

1. Pada aspek kognitif, minat dapat menjadi dorongan dalam mencapai tujuan atau kebutuhan, sehingga segala sesuatu yang dikerjakannya memberi nilai tambah bagi dirinya, sedangkan pada aspek sikap, sesuatu yang dikerjakannya akan memberi kesenangan, kebahagiaan dan tidak menimbulkan kebosanan. Oleh karena minat menjadi sumber energi untuk melaksanakan kegiatan dalam mencapai tujuan atau kebutuhannya.

2. Minat menekankan kepada pemilihan dimana antara suka dan tidak suka nilai-nilai, objek, keterampilan-keterampilan, pengertian, kecakapan/pengalaman, kesenangan, keinginan atau kemauan, perhatian, dan partisipasi seseorang pada suatu kegiatan yang disukainya.

3. Minat menekankan keharusan sebagai suatu sambutan yang sadar, jika tidak minat itu tidak akan punya arti sama sekali.

Berdasarkan pokok pikiran yang diambil dari berbagai ahli, maka untuk kepentingan minat belajar siswa dapat disimpulkan bahwa minat merupakan suatu faktor yang berasal dari dalam diri manusia dan berfungsi sebagai pendorong dalam berbuat sesuatu yang memberikan individu ke arah perhatian, kesenangan, keinginan dan pengalaman secara sadar, sedangkan aspek perilaku afektif minat memiliki karakteristik pada arah, intensitas, dan target.

Perilaku individu tidak berdiri sendiri, selalu ada hal yang mendorongnya untuk sampai pada suatu tujuan yang ingin dicapainya. Kekuatan yang menjadi pendorong atau penggerak individu melakukan kegiatan untuk mencapai tujuan disebut motivasi. (Kasim, 2005)

Motivasi dapat diartikan sebagai dorongan untuk mengerjakan tugas dengan sebaik-baiknya dengan mengacu kepada standar keunggulan. (Djaali, 2008). Untuk itu motivasi perlu dimiliki oleh setiap siswa. Siswa yang motivasi tinggi; memiliki inisiatif untuk melakukan kegiatan berprestasi, bekerja dengan intensitas tinggi, sabar dalam menghadapi kegagalan dan memilih tugas yang taraf kesulitannya sedang. Siswa yang mengandalkan usaha dan kemampuan untuk mencapai tujuan maka dia akan bangga dengan keberhasilannya. Rasa penghargaan yang tinggi terhadap diri sendiri ini meningkatkan keinginan mereka berinisiatif 
pada langkah-langkah berprestasi berikutnya, dan cenderung ingin melanjutkan hal yang berharga ini, sedangkan siswa yang memiliki motivasi rendah karena mengandalkan faktor eksternal daripada internal maka harga diri mereka tidak tinggi dan tidak memiliki inisiatif untuk berprestasi.

Siswa dengan motivasi tinggi dapat mengatasi kemungkinan lebih berhasil pada tugas berikutnya dengan merencanakan usaha yang lebih keras, sedangkan siswa yang motivasi rendah karena menganggap sukses berasal dari keberuntungan dan gagal karena ketidakmampuan, maka mereka hanya berpandangan bahwa kegagalan demi kegagalan yang akan diperolehnya pada tugas berikutnya. Hal ini mengakibatkan usaha mereka untuk berprestasi semakin menurun.

Menurut pendapat Johnson dan switzgebel (dalam Djaali, 2008) dapat disimpulkan bahwa siswa yang memiliki motivasi tinggi memiliki karakteristik sebagai berikut.

1. Menyukai situasi atau tugas yang menuntut kemampuan pribadi atas hasil-hasilnya bukan atas dasar untung-untungan, nasib, atau kebetulan.

2. Memilih tujuan yang realistis tetapi menantang dari tujuan yang terlalu mudah dicapai atau terlalu besar resikonya.

3. Mencari situasi atau pekerjaan dimana ia memperoleh umpan balik dengan segera dan nyata untuk menentukan baik atau tidaknya hasil pekerjaannya.

4. Senang bekerja sendiri dan bersaing untuk mengungguli orang lain.

5. Mampu menangguhkan keinginannya demi masa depan yang lebih baik.

6. Tidak tergugah untuk sekedar mendapatkan uang, ia akan mencari apabila hal-hal tersebut merupakan lambang prestasi, suatu ukuran keberhasilan.

Berdasarkan uraian yang telah dikemukakan di atas, dapat disimpulkan bahwa motivasi yang dikemukakan dalam penelitian ini adalah usaha meningkatkan atau mempertahankan setinggi mungkin kecakapan yang dimiliki untuk mencapai tujuan dan peran guru dalam membantu memotivasi siswa dengan berbagai cara yang dimiliki dan dapat digunakan.

Walaupun banyak pengertian motivasi yang dikemukakan oleh para ahli, dan dengan sudut pandang yang berbeda namun pada dasarnya mempunyai inti yang sama yaitu sebagai pendorong yang mengubah energi dalam diri seseorang ke dalam aktivitas nyata untuk mencapai tujuan tersebut. Berlinger \& Gage (dalam Kasim, 2005) mengungkapkan bahwa motivasi mengarahkan tingkah laku dan menentukan kekuatan dari tingkah laku. Menurut Mc Donald (dalam Hamalik, 2008), "motivation is an energy change within the person characterized by affective arousal and anticipatory goal reaction", yang diartikan bahwa motivasi adalah suatu perubahan energi dalam diri (pribadi) seseorang yang ditandai dengan timbulnya perasaan dan reaksi untuk mencapai tujuan.

Siswa dengan motivasi tinggi dapat mengatasi kemungkinan lebih berhasil pada tugas berikutnya dengan merencanakan usaha yang lebih keras, sedangkan siswa yang motivasi rendah karena menganggap sukses berasal dari keberuntungan dan gagal karena ketidakmampuan, maka mereka hanya berpandangan bahwa kegagalan demi kegagalan yang akan diperolehnya pada tugas berikutnya. Hal ini mengakibatkan usaha mereka untuk berprestasi semakin menurun.

Peran guru dalam memotivasi belajar siswa sangat penting agar siswa dapat berprestasi dengan baik. Untuk itu guru dapat melakukan upaya-upaya, kiat yang dapat dilakukan untuk memotivasi belajar siswa. Adapun upaya yang dilakukan untuk memotivasi belajar menurut DeCecco dan Grawford (2004) di antaranya: 
1. Menggairahkan siswa

Dalam kegiatan rutin sehari-hari pengajar harus berusaha menghindari hal-hal yang mono ton dan membosankan. Guru harus selalu memberikan pada siswa cukup banyak hal-hal yang perlu dipikirkan dan dilakukan. Guru harus memelihara minat siswa dalam belajar, yaitu dengan memerikan kebebasan tertentu untuk berpindah dari aspek ke lain aspek pelajaran dalam situasi belajar.

2. Memberikan harapan realistis

Guru harus memilihara harapan-harapan siswa realistis, dan memodifikasi harapanharapan yang kurang atau tidak realistis. Untuk itu, pengajar perlu memiliki pengetahuan yang cukup mengenai keberhasilan dan kegagalan akademis siswa pada masa lalu. Dengan demikian, pengajar dapat membedakan antara harapan-harapan yang realistis, pesimistis, atau terlalu optimis. Bila siswa terlalu banyak mengalami krgagalan, maka guru harus memberi sebanyak mungkin keberhasialan pada siswa.

3. Memberikan inisiatif

Bila siswa mengalami keberhasilan, pengajar diharapkan memberikan hadiah pada siswa (dapat berupa pujian, angka yang baik, dan lain sebagainya) atas keberhasilannya, sehingga siswa terdorong untuk melakukan usaha lebih lanjut guna mencapai tujuantujuan pengajaran. Sehubungan dengan hal ini, umpan balik merupakan hal yang sangat berguna untuk meningkatkan usaha siswa.

4. Mengarahkan

Penagajar harus menagarahkan tingkah laku siswa, dengan cara menunjukkan pada siswa hal-hal yang dilakukan secara tidak benar dan meminta pada mereka melakukan sebaikbaiknya. Gagne dan Berliner (1984) menyarankan juga sejumlah cara meningkatkan motivasi siswa, tanpa harus melakukan reorganisasi kelas secara besar-besaran yaitu:

a. Pergunakan pujian verbal

Penerimaan sosial yang mengutip suatu tingkah laku yang diinginkan dapat menjadi alat yang cukup dapat dipercaya untuk mengubah prestasi dan tingkah laku akademis ke arah yang diinginkan. Kata-kata 'bagus', 'baik', 'pekerjaan yang baik', yang diucapkan segera setelah siswa melakukan tingkah merupakan pembangkit motivasi yang besar. Penerimaan sosial merupakan suatu penguat atau insentif yang relatif konsisten.

b. Pergunakan tes dalam nilai secara bijaksana

Kenyataan bahwa tes dan nilai dipakai sebagai dasar berbagai hadiah sosial, (seperti penerimaan lingkungan, promosi, pekerjaan yang baik, uang yang lebih banyak dan sebagainya) menyebabakan tes dan nilai dapat menjadi suatu kekuatan untuk memotivasi siswa. Siswa belajar bahwa ada keuntungan yang diasosiasikan dengan nilai yang tinggi. Dengan demikian, memberikan tes dan nilai mempunyai efek dalam memotivasi siswa untuk belajar. Akan tetapi, tes dan nilai harus dipakai secara bijaksana, yaitu memberikan informasi kepada siswa dan untuk menilai penguasaan dan kemajuan siswa, bukan untuk menghukum atau membanding-bandingkannya denagn siswa lain. Penyalahgunaan tes dan nilai akan mengakibatkan menurunnya keinginan siswa untuk berusaha dengan baik.

c. Bangkitkan rasa ingin tahu siswa dan keinginannya untuk mengadakan eksplorasi. Dengan melontarkan pertanyaan atau masalah-masalah, pengajar dapat menimbulkan suatu konflik konseptual yang merangsang siswa untuk bekerja. Motivasi akan berakhir bila konflik terpecahkan atau bila timbul rasa bosan untuk memecahkannya.

d. Untuk tetap mendapatkan perhatian, sekali-sekali pengajar dapat melakukan hal-hal yang luar biasa, misalnya meminta siswa menyusun soal-soal tes, menceritakan problem guru dalam belajar, dan sebagainya.

e. Merangsang hasrat siswa dengan jalan memberikan pada siswa sedikit contoh hadiah yang akan diterimanya bila ia berusaha untuk belajar. Berikan pada siswa penerimaan sosial, sehingga ia tahu apa yang dapat diperolehnya jika ia berusaha lebih lanjut. 
Dalam menerapkan hal ini, pengajar perlu membuat urutan pengajaran, sehingga siswa dapat memperoleh sukses dalam tugas-tugas permulaan.

f. Agar siswa lebih mudah memahami bahan pengajaran, pergunakan materi-materi yang sudah dikenal sebagai contoh.

g. Terapkan konsep-konsep atau prinsip-prinsip dalam konteks yang unik dan luar biasa, agar siswa jadi lebih terlibat.

h. Meminta pada siswa untuk mempergunakan hal-hal yang sudah dipelajari sebelumnya.

i. Pergunakan simulasi dan permainan.

j. Perkecil daya tarik sistem motivasi yang bertentangan.

k. Perkecil konsekuensi-konsekuensi tidak menyenangkan dari keterlibatan siswa.

1. Pengajar perlu memahami dan mengawasi suasana sosial di lingkungan sekolah, karena hal ini besar pengaruhnya atas diri siswa.

m. Pengajar perlu memahami hubungan kekuasaan antara guru dan siswa.

Belajar merupakan proses yang berlangsung terus menerus sepanjang hidup, baik melalui pendidikan formal, informal maupun melalui pengalaman hidup sehari-hari. Menurut Witherington (dalam Sukmadinata, 2007), "belajar merupakan perubahan dalam kepribadian, yang dimanivestasikan sebagai pola-pola respon yang baru yang berbentuk keterampilan, sikap, kebiasaan, pengetahuan dan kecakapan”.

Masih dalam Sukmadinata (2007), pendapat yang hampir sama dikemukakan oleh Crow and Crow dan Hilgard, menurut Crow and Crow "belajar adalah diperolehnya kebiasaankebiasaan, pengetahuan dan sikap baru". Sedangkan menurut Hilgard, "belajar adalah suatu proses di mana suatu prilaku muncul atau berubah karena adanya respon terhadap sesuatu situasi". Selanjutnya menurut Slameto (2003), belajar adalah suatu proses usaha yang dilakukan untuk memperoleh perubahan tingkah laku yang baru secara keseluruhan sebagai hasil pengalaman sendiri dalam interaksi dengan lingkungannya. Pengertian belajar tersebut secara luas dapat diartikan bahwa belajar akan menghasilkan perubahan-perubahan, yaitu dalam bentuk adanya perubahan pengetahuan dari yang tidak tahu, menjadi tahu.

Tentang belajar ini, Soemanto (2006) juga mengemukakan bahwa:

Belajar merupakan proses dasar dari perkembangan hidup manusia. Dengan belajar, manusia melakukan perubahan-perubahan kualitatif individu sehingga tingkah lakunya berkembang. Semua aktivitas prestasi hidup manusia tidak lain adalah hasil belajar. Belajar itu bukan sekedar pengalaman. Belajar adalah suatu proses, dan bukan suatu hasil. Oleh karena itu, belajar berlangsung secara aktif dan integratif dengan menggunakan berbagai bentuk perbuatan untuk mencapai suatu tujuan.

Selanjutnya, Kunandar (2007) mengemukakan bahwa belajar adalah suatu aktivitas yang mengharapkan perubahan tingkah laku pada diri individu yang belajar. Perubahan tingkah laku terjadi karena usaha individu yang bersangkutan.

Dari pengertian belajar di atas, dapat disimpulkan bahwa manusia yang melakukan proses belajar akan timbul perubahan tingkah laku sesuai dengan perkembangannya yang berlangsung secara aktif dan integratif. Proses perubahan tingkah laku pada diri seseorang berlangsung secara terus-menerus, sesuai dengan perkembangan psikis pada dirinya. Selanjutnya, manusia yang mengikuti proses belajar akan mengalami perubahan dalam sikap, maupun tingkah laku. Demikian halnya dengan proses belajar di sekolah, keberhasilan siswa dalam belajar ditandai dengan terselesaikannya tugas-tugas akademik yang diberikan guru di sekolah.

Sedangkan prestasi belajar adalah kemampuan yang diperoleh anak setelah melalui kegiatan belajar (Jihad dan Haris, 2008). Menurut Sudjana (2002), hasil belajar adalah kemampuan 
yang dimiliki siswa setelah ia menerima pengalaman belajarnya. Dari kedua pengertian tersebut dapat disimpulkan bahwa hasil belajar adalah kemampuan yang dimiliki siswa setelah dilakukan proses belajar mengajar sesuai dengan tujuan pembelajaran.

Dalam bahasa Indonesia istilah hasil belajar sering diartikan menjadi prestasi, yang berarti hasil yang telah dicapai (dari yang telah dilakukan atau dikerjakan). Istilah prestasi selalu dihubungkan dengan aktivitas tertentu, bahwa dalam setiap proses akan selalu terdapat hasil nyata yang dapat diukur dan dinyatakan sebagai hasil belajar.

Muhibbin Syah menjelaskan bahwa prestasi belajar merupakan taraf keberhasilan siswa dalam mempelajari materi pelajaran di sekolah yang dinyatakan dalam bentuk skor yang diperoleh dari hasil tes mengenai sejumlah materi pelajaran tertentu. (Syah, 2004). Hal tersebut menunjukkan bahwa istilah prestasi belajar digunakan untuk menyebut berbagai macam hasil kegiatan atau usaha. Hal ini sesuai dengan kenyataan yang sering kita temukan dalam kehidupan sehari-hari, kita sering menggunakan istilah prestasi untuk menyebut hasil yang dicapai dalam berbagai usaha, prestasi usaha, prestasi belajar dan sebagainya.

Dalam proses pendidikan, prestasi dapat diartikan sebagai hasil proses belajar mengajar yakni penguasaan, perubahan emosional atau perubahan tingkah laku. Dalam penelitian ini, istilah prestasi yang dimaksud adalah hasil belajar yang dicapai siswa yang merupakan hasil dari proses pembelajaran dan dapat diukur dengan alat atau tes tertentu.

Belajar sering dipergunakan dalam arti yang sangat luas yakni untuk bermacam-macam aturan terhadap apa yang telah tercapai oleh siswa, misalnya tugas-tugas pekerjaan rumah, ulangan harian, tes lisan yang dilakukan selama pelajaran berlangsung, tes akhir semester dan sebagainya. Dalam penelitian ini, disimpulkan bahwa prestasi belajar adalah tingkat kemampuan aktual yang dapat diukur, berupa penguasaan ilmu pengetahuan, sikap dan keterampilan yang dicapai oleh siswa sebagai hasil dari apa yang dipelajarinya.

\section{Metodologi Penelitian}

Metode penelitian yang digunakan dalam penelitian ini adalah survei, dengan bentuk penelitian uji korelasional. Penelitian survei adalah penelitian yang mengambil sampel dari satu populasi dan menggunakan kuesioner sebagai alat pengumpulan data yang pokok (Singarimbun dan Efendi, 2006). Masih menurut Singarimbun, penelitian survei dapat digunakan untuk maksud penjelasan (explanatory atau confirmatory), yakni untuk menjelaskan hubungan kausal dan pengujian hipotesis. Survei bukanlah bermaksud hanya mengetahui status gejala, tetapi juga menentukan kesamaan status dengan cara membandingkannya dengan standar yang sudah dipilih atau ditentukan. Di samping itu, juga untuk membuktikan atau membenarkan suatu hipotesis (Arikunto, 2006). Winarno Surakhmad (dalam Arikunto, 2006) bahwa umumnya survei merupakan cara mengumpulkan data dari sejumlah unit atau individu dalam waktu (atau jangka waktu) yang bersamaan.

Berdasarkan teori tersebut di atas, maka penelitian ini lebih tepat menggunakan survei korelasional, karena dalam penelitian ini akan diungkap fakta-fakta atau gejala-gejala hubungan antara variabel yang satu dengan variabel yang lain. Dengan tujuan untuk mencari hubungan antara minat belajar siswa dan persepsi atas upaya guru dalam memotivasi siswa terhadap prestasi belajar Bahasa Indonesia.

Sesuai dengan variabel penelitian yang telah disebutkan, ada tiga jenis data yang dikumpulkan dalam penelitian ini. Ketiga data tersebut dijaring dengan mengambil data dari kuesioner untuk variabel persepsi atas upaya guru dalam memotivasi siswa terdiri dari 15 pertanyaan dan untuk variabel minat belajar kuesioner yang terdiri atas 30 pertanyaan, yaitu dengan skala sikap Likert, sedangkan untuk variabel prestasi belajar Bahasa Indonesia melihat hasil penilaian sehari-hari. 
Pengumpulan data dilakukan dengan menggunakan instrumen yang akan diujicobakan kepada 78 orang siswa. Untuk sampel penelitian dipilih secara random dari seluruh siswa yang ada. Siswa yang sudah terpilih secara random itu kemudian dikumpulkan dalam satu ruangan, lalu diberikan pengarahan tentang maksud dan tujuan dari penelitian ini, serta cara pengisian kuesioner. Pengisian kuesioner motivasi berprestasi dilaksanakan selama kurang lebih 60 menit.

Untuk menyusun instrumen penelitian, peneliti melakukan langkah-langkah sebagai berikut:

1. Menjabarkan/mengembangkan variabel penelitian secara operasional, menjadi indikatorindikator yang diperoleh dari teori untuk disusun menjadi butir-butir pernyataan.

2. Mengadakan konsultasi dengan pembimbing untuk mendapatkan masukan apakah indikator yang dikembangkan sudah logis dan rasional, yang berasal dari teori variabel terkait.

3. Mengadakan uji coba untuk melihat relibitas dan validitas instrumen.

Penyusunan kuesioner berbentuk skala sikap Likert dengan lima pilihan dengan skor 5 untuk sangat setuju (SS), 4 untuk setuju (S), 3 untuk tidak tahu (TT), 2 untuk tidak setuju (TS), dan 1 untuk sangat tidak setuju (STS).

\section{Hasil dan Pembahasan}

Penelitian ini bertujuan untuk mengetahui pengaruh minat belajar siswa dan persepsi atas upaya guru dalam memotivasi belajar siswa secara bersama-sama terhadap prestasi belajar Bahasa Indonesia.

Pengaruh Minat Belajar Siswa dan Persepsi Atas Upaya Guru dalam Memotivasi Belajar Siswa secara Bersama-sama terhadap Prestasi Belajar Bahasa Indonesia.

Minat belajar siswa dan persepsi atas upaya guru dalam memotivasi belajar siswa secara bersama-sama terhadap prestasi belajar bahasa Indonesia tergolong sedang. Tingkat minat belajar siswa dan persepsi atas upaya guru dalam memotivasi belajar siswa terhadap prestasi belajar bahasa Indonesia siswa signifikan. Kondisi pengaruh minat belajar siswa dan persepsi atas upaya guru dalam memotivasi belajar siswa terhadap prestasi belajar bahasa Indonesia siswa tercermin melalui adanya kecenderungan minat belajar siswa yang berbanding lurus dalam memberikan pengaruh terhadap prestasi belajar bahasa Indonesia siswa. Hal ini menandakan bahwa minat dan motivasi belajar dalam kegiatan belajar memberikan kontribusi terhadap prestasi belajar yang dimiliki siswa kelas IX SMP Swasta Depok. Hal tersebut terjadi dapat disebabkan oleh proses pembelajaran yang dilakukan dalam kegiatan belajar mengajar di kelas telah menekankan pada aspek motivasi siswa dan minat belajar. Dalam pembelajaran bahasa Indonesia dibutuhkan adanya minat siswa sendiri hingga mereka dengan sendirinya menyukai dan mengikuti pelajaran dengan senang dan mendapatkan prestasi belajar yang baik. Hasil penelitian ini menyiratkan peran guru bahasa Indonesia untuk memberikan perhatian pada minat dan motivasi belajar siswa karena guru merupakan ujung tombak dalam proses siswa mendapatkan prestasi belajar yang baik.

\section{Pengaruh Minat Belajar Siswa terhadap Prestasi Belajar Bahasa Indonesia}

Minat belajar siswa yang dimiliki siswa dalam kegiatan belajar memberikan pengaruh yang cukup terhadap prestasi belajar bahasa Indonesia yang dimiliki siswa. Tingkat pengaruh minat belajar siswa terhadap prestasi belajar bahasa Indonesia tergolong signifikan. Kondisi ini terjadi karena siswa memiliki minat yang baik terhadap pelajaran bahasa Indonesia maka prestasi belajarnya juga akan baik. Peran gurulah yang diharapkan agar siswa terus memiliki minat yang baik terhadap pelajaran bahasa Indonesia yang masih sering dipandang mudah oleh sebagian siswa karena mereka menganggap menggunakan bahasa Indonesia sebagai bahasa sehari-harinya, karena itu guru harus terus menumbuhkan minat siswa dengan 
berbagai metode belajar yang bervariatif sehingga siswa memiliki minat yang baik dan akhirnya memperoleh prestasi belajar yang baik.

\section{Pengaruh Persepsi Atas Upaya Guru dalam Memotivasi Belajar Siswa terhadap Prestasi Belajar Belajar Bahasa Indonesia}

Persepsi atas upaya guru dalam memotivasi belajar siswa memberikan pengaruh yang cukup baik terhadap prestasi belajar siswa. Hal ini terjadi karena semakin baik upaya guru dalam memotivasi siswa, maka akan semakin baik pula prestasi belajarnya. Untuk memperoleh prestasi belajar yanga baik dalam pendidikan, maka siswa yang ingin memperoleh prestasi belajar yang baik akan berusaha untuk meningkatkan kemampuannya dengan sungguhsungguh sebagai rasa tanggung jawabnya. Namun bila menemukan kesulitan dalam belajar, maka mereka akan berusaha dengan segala kemampuan yang dimiliki untuk mengatasi kesulitan tersebut. Tugas guru sebagai motivatorlah yang dapat membangkitkan motivasi siswa sehingga siswa menjadi bersemangat mengikuti pelajaran dan akhirnya mendapatkan prestasi belajar yang baik juga.

\section{Simpulan dan Saran \\ Simpulan}

Berdasarkan uraian di atas peneliti menyimpulkan beberapa hal sebagai berikut:

1. Terdapat pengaruh minat belajar siswa dan persepsi atas upaya guru dalam memotivasi belajar siswa secara bersama-sama terhadap prestasi belajar bahasa Indonesia.

2. Terdapat pengaruh minat belajar siswa terhadap prestasi belajar bahasa Indonesia siswa. Berdasarkan hal tersebut maka semakin baik minat belajar siswa diikuti oleh semakin baiknya prestasi belajar bahasa Indonesia siswa.

3. Terdapat pengaruh persepsi atas upaya guru dalam memotivasi belajar siswa terhadap prestasi belajar bahasa Indonesia. Berdasarkan hal tersebut, maka semakin baik persepsi atas upaya guru dalam memotivasi belajar siswa diikuti oleh semakin baiknya prestasi belajar bahasa Indonesia siswa.

\section{Saran}

1. Guru bahasa Indonsia hendaknya agar terus memotivasi siswa agar menyenangi pelajaran bahasa Indonesia dengan menggunakan metode yang beragam dan dapat menarik minat siswa.

2. Siswa hendaknya lebih menumbuhkan minat dan rasa ketertarikan terhadap pelajaran bahasa Indonesia.

3. Civitas akademika sebagai pembelajar tingkat tinggi hendaknya selalu memberikan minat dan motivasi agar para pelajar senang dan berminat mengikuti pelajaran bahasa Indonesia dan mendapatkan prestasi belajar yang baik.

4. Rasa bangga berbahasa Indonesia hendaknya ditanamkan kepada siswa melalui kegiatan yang mendidik serta menghibur.

\section{Daftar Pustaka}

Arikunto, Suharsimi. (2006). Prosedur Penelitian Suatu Pendekatan Praktik. Jakarta: PT Rineka Cipta.

Arthur. (1963). Cara Belajar yang Efisien. Yogyakarta: Pusaka Kemajuan Studi.

Barbirin, Raminah. (1990). Psikologi Belajar. Bandung: Tarsito.

Dececco dan Crawford. (2004). Belajar dan Faktor-faktor yang Mempengaruhinya. Jakarta: Rineka Cipta.

Djaali. (2008). Psikologi Pendidikan. Jakarta: Bumi Aksara.

Djamarah, S. B. (2006). Psikologi Belajar. Jakarta: Rineka Cipta. 
Gagne dan Berliner. (1984). Strategi Belajar. Jakarta: Wijaya.

Garet. (1965). Belajar dan Pembelajaran. Jakarta: Rineka Cipta.

Hamalik, Oemar. (2008). Kurikulum dan Pembelajaran. Jakarta: PT Bumi Aksara.

Jihad, Asep dan Haris, Abdul. (2008). Evaluasi Pembelajaran. Yogyakarta: Multi Pressindo.

Kasim, Anwar. (2005). Bimbingan Konseling Belajar. Jakarta: Universitas Jakarta.

Kunandar. (2007). Guru Profesional. Jakarta: PT Raja Grafindo Persada.

Nasution. (1981). Pemahaman Individu. Surabaya: Usaha Nasional.

Singarimbun, Masri \& Efendi, Sofian (ed). (2006). Metode Penelitian Survei. Jakarta: LP3ES.

Slameto. (2003). Belajar dan Fakta yang Mempengaruhinya. Jakarta: Rineka Cipta.

Soemanto, Wasty. (2006). Psikologi Pendidikan. Jakarta: PT Rineka Cipta.

Sudjana, Nana. (2002). Penilaian Hasil Proses Belajar Mengajar. Bandung: Rosdakarya.

Sukmadinata, N. S. (2007). Landasan Psikologi Proses Pendidikan. Bandung: PT Remaja Rosdakarya.

Syah, Muhibbin. (2004) Psikologi Pendidikan dengan Pendekatan Baru. Bandung: Remaja Rosdakarya.

Thorndike dan Elizabeth. (1997). Bimbingan dan Konseling Individu. Jakarta: Gramedia. 